\title{
Relationship of Stress and Sleep Disorders in Faculty of Medical Students of Malahayati University during COVID-19 Pandemic
}

\author{
Hasmarullah Fasya $^{1 *}$, Octa Reni Setiawati ${ }^{2}$, Ismalia Husna ${ }^{3}$, Woro Pramesti ${ }^{4}$ \\ 1, 3) Medical Study Program, Faculty of Medicine, Malahayati University, Indonesia \\ 2) Department of Psychology, Faculty of Medicine, Malahayati University, Indonesia \\ 4) Department of Science Psycho House, Psychiatric Hospital Province of Lampung, Indonesia \\ *Corresponding author: hasmarullahfasya1@gmail.com
}

\begin{abstract}
Background: The World Health Organization (WHO) announced on March 11, 2020 that the disease outbreak caused by the COVID-19 coronavirus is a global pandemic. Therefore those educational institutions ranging from preschool to tertiary levels are closed for a while. Lecture activities are carried out remotely through Online applications that support lecture activities. Educators and parents are confused about accompanying their children to study at home, while students are confused or stressed by online learning methods and extensive learning with many tasks, especially during the COVID-19 pandemic. This stress can cause adverse effects, such as high blood pressure, dizziness, sadness, attention, insomnia and other sleep abnormality, hypersensitivity, depression, etc. In some cases, stress can cause a variety of discomfort. Purposes: to find out the relationship between stress and sleep disorders in the COVID-19 pandemic. Methods: The test conducted in this study is the Spearman test and quantitative type with analytic design and cross-sectional approach. The measuring instruments used were the DASS 42 questionnaire (Depression Anxiety Stress Scales 42) and the PSQI questionnaire. Results: respondents in this study were 60 respondents. The largest distribution among the stress variables was moderate stress level $(40 \%)$, while the largest type of the two levels of sleep disorder is bad level $(80 \%)$, and the results of the correlation analysis on the stress variable with sleep disorders obtained $\mathrm{P}=0.000$ and the result of the correlation coefficient $r=0.720$. Conclusion: Based on the results of the Spearman test on the relationship between stress and sleep disorders, the $\mathrm{P}$ value was $0.000(\mathrm{P}<0.05)$ indicating that there was a relationship between sleep disorders and stress, while the $r$ value was 0.720 or positive correlation, meaning that the higher the stress level, the higher the sleep disturbance, vice versa.
\end{abstract}

Keywords: COVID-19, sleep disorders, stress

\section{INTRODUCTION}

Coronavirus Disease 19 (COVID-19) is an infectious disease caused by Severe Acute Respiratory Syndrome Coronavirus 2 (SARS-CoV-2). SARS-CoV-2 is a new type of coronavirus that has never happened to humans before. There are at least two types of the virus that is the Middle East respiratory syndrome (MERS) and Indian severe acute respiratory syndrome (SARS). Common symptoms and signs of being infected with COVID-19 include coughing, fever, and shortness of breath. The average incubation period is 5-6 days, and the longest incubation period is 14 days. In the case of COVID-19 which is severe, it can 
lead to pneumonia, acute respiratory distress syndrome, kidney failure, and even death (1).

In its development, the plague first time the disease COVID-19 that occurred in Wuhan, China from December 2019 to April 2020 has spread to 210 countries. With the nature and characteristics of its very human-to-human spread, coupled with high human mobility and across borders of each country, the COVID-19 virus becomes very dangerous. According to Worldometer data globally on 23 April 2020, the number of positive cases that was caused by a virus has reached 2.7 million, with the United States, Spain, and Italy ranked three major cases of the virus (2).

In Indonesia, on March 2, 2020, the President began to know and announce it with two positive victims, namely Indonesian citizens. Of all the countries in the ASEAN region, Indonesia is a country with a positive cases and the highest death rate due to COVID 19 (3). the growth of COVID-19 shows that as of November 20, 2020 , there was an increase in cases of positive victims of COVID-19 by 483,518 people, and the total number of patients who recovered reached 84.1 percent, while the number of victims who died from this virus, if calculated, has reached 15,9 percent . And in Lampung Province, there were 2,891 positive victims of COVID-19, and the total number of recovered patients reached 95 percent, while the number of victims who died from this virus, if calculated, totaled 5 percent people (1).

Educational institutions ranging from preschool to tertiary levels are closed for a while. Students in tertiary institutions also feel the impact and consequences of COVID-19. Lecture activities are carried out remotely through applications that support lecture activities. This kind of activity is a form of government effort in Indonesia in minimizing the increase of the cases number that continue in the COVID19 pandemic and experienced an increase that is significant (4).

Many schools are implementing methods of giving online assignments for students. This task is carried out through various available social media, especially WhatsApp groups. In an emergency such as the present, it is a form of work home that is effective in learning distance away. Because it is not feasible to introduce the concept of the curriculum in a learning face-to-face. In face-to-face learning, the concepts and learning objectives will be conveyed first. Then learning will continue until it is understood and developed. Stages are rated as experiencing progress that is bad in situations of emergency such as now (5).

Research that is done by Livana et al. Educators and the parents are confused to accompany their children learn at home, while the students are confused or stressed against methods of learning online and learning extensively with the task that much, especially at the time of the pandemic COVID-19 (6).

Stress is a feeling a person experiences when facing a stressful situation. According to the opinion of Cameron and Meichenbaum, stress is divided into several kinds of forms, depending on the personality of individuals who feel it, the ability to deal with the stress that (copying skills), and the nature of the stressors they experienced. Where if people can not reduce stress, then it can appear by a physical disorder, behavior to mental disorder with a variety of factors such as frustration, conflict, tension, and crisis (6).

The pressure of this stress can cause adverse effects, such as high blood 
pressure, dizziness, sadness, lack of attention, insomnia, another sleep abnormality, hypersensitivity, depression, etc. In some cases, stress can cause various discomforts (7), and if their need for sleep duration is not fulfilled, the result will be fatigue, anxiety, increased stress, and lack of concentration in daily activities. If the sleep duration is insufficient than normal needs it can affect the role of protein synthesis in repairing damaged cells to be decreased (8).

Sleep is an important requirement for everyone because everyone needs enough rest and sleep so that the body can function normally. During rest and sleep, the body will carry out a recovery process to restore the body's immune system to its best condition. Sleep is a very important process for humans because in sleep there is a recovery process that can be used to restore the human condition to its original state so that a previously tired body can recover. Obstruction of the recovery process will cause the body's organs to not function optimally, as a result, those who are sleep deprived will quickly feel tired and lose concentration (9).

Sleep disturbances are also known to cause morbidity significant. There are several serious effects to sleep disturbances in adults such as excessive daytime sleepiness, attention and memory disorders, depressed mood, frequent falls, improper use of hypnosis, and decline quality of life. Death rate, heart disease rate and cancer was higher in someone who slept more of 9 hours or less than 6 hours per day when compared with someone who sleeps between 7-8 hours per day (10).

In the research of Wicaksono et al., a study was conducted on the Dominant Factors that are related to Sleep Quality in Nursing faculty student at Airlangga
University. The results of this study indicate that there is a relationship between stress and sleep quality. Based on research results there are 12 respondents $(24 \%)$ who experiencing stress at normal levels however poor sleep quality data obtained from questionnaires that have been filled in by respondents, they often are having difficulty initiating sleep and they also often wake up at night day, resulting in less sleep from 7-8 hours per day. This can caused due to factors other than the stress experienced by respondents who can be annoying sleep quality, such as fatigue, environment, diet, medicine, disease and lifestyle (8). The results showed that there were 7 topics related to the causes of student stress during the COVID-19 pandemic. Many respondents stated that one of the causes of student stress during the COVID-19 pandemic was college assignments (6).

Based on the above research, the authors are interested in conducting research on the relationship between stress and sleep disorders in 2019 medical students at the time of the COVID 19 pandemic.

\section{METHODS}

This study used a quantitative method with an analytic design and a cross-sectional approach which aims to determine the relationship between stress and sleep disorders. This research was conducted at Malahayati University in January 2021, with an accidental sampling technique, Accidental sampling is a sampling method with integrated object and subject opportunities and the sample in this study were all students of the Faculty of Medicine, Malahayati University 2019, total were 60 people. Inclusion criteria in research: 
1. Students of the 2019 Malahayati University Faculty of Medicine who are willing to fill out the questionnaire data;

2. Active in lecture academic activities;

3. Willing to be a respondent.

Exclusion criteria:

1. Students of the 2019 Malahayati University Faculty of Medicine who are unwilling to fill out the questionnaire data;

2. Transfer students from other universities.

This study uses the DAS42 questionnaire for Stress Levels and the PSQI questionnaire for Sleep Disorder assessment. This research was using a test that is used a Kolmogorov Smirnov normality test since the sample is $>50$, while for the data analysis using univariate and bivariate analysis, where analysis of bivariate using Spearman correlation test because the data is not distributed normally. Data processing in this study using the spss application. The study had been approved by the Ethics Committee of Malahayati University on January $11^{\text {st }}, 2021$, with a reference number of 1356/EC/KEP-UNMAL/1/2021.

\section{RESULT}

The results of this study was presented in the following table. Table 1 was shown that the moderate stress level was 24 respondents (40\%), the mild stress level was 20 respondents $(33.3 \%)$, the normal stress level was 13 respondents (21.7\%), the severe stress level was 3 respondents $(5.0 \%)$ and the level of very severe stress amounted to 0 respondents $(0 \%)$. Table 2 was shown that level of sleep disorders from averages respondents was bad, because it showed $80 \%$ of $100 \%$.

\section{Table 1. Distribution of Stress Levels during the COVID - 19 Pandemic}

\begin{tabular}{lcc}
\hline Stress Level & $\begin{array}{c}\text { Frequency } \\
(\mathbf{n})\end{array}$ & $\begin{array}{c}\text { Percentage } \\
(\boldsymbol{\%})\end{array}$ \\
\hline Very Severe & 0 & 0 \\
Severe & 3 & 5.0 \\
Moderate & 24 & 40.0 \\
Light & 20 & 33.3 \\
Normal & 13 & 21.7 \\
Total & 60 & 100 \\
\hline
\end{tabular}

Table 2. Distribution of Sleep Disorders during when Pandemic COVID 19

\begin{tabular}{lcc}
\hline $\begin{array}{l}\text { Level of Sleep } \\
\text { Disorders }\end{array}$ & $\begin{array}{c}\text { Frequency } \\
(\mathbf{n})\end{array}$ & $\begin{array}{c}\text { Percentage } \\
(\%)\end{array}$ \\
\hline Good & 12 & 20 \\
Bad & 48 & 80 \\
Total & 60 & 100 \\
\hline
\end{tabular}

Table 3. Spearman Correlation Test for the Relationship between Stress and Sleep Disorders

\begin{tabular}{lccc}
\hline \multicolumn{1}{c}{ Variable } & N & Sig & $\begin{array}{c}\text { Coefficient } \\
\text { correlation (r) }\end{array}$ \\
\hline Stress & 60 & 0,000 & 0.720 \\
Sleep Disorders & 60 & 0,000 & 0.720 \\
\hline
\end{tabular}

Table 3 was correlation test data of stress and sleep disorders, and it showed that Pvalue was 0.000 and coefficient correlation was 0.720 .

\section{DISCUSSION}

Stress

Stress is a physical, chemical, and emotional factor that can cause stress on the body or mentally and can be a factor in the onset of disease. Stress is the body's generalized non-specific response to any factor that addresses, or threatens to overcome, the body's compensatory ability 
to maintain homeostasis. The factors that cause stress can be divided into internal factors and external factors (11).

Internal factors come from within the individual student himself, for example, the physical condition, motivation, and personality type of the student himself. Meanwhile, external factors usually come from outside the individual such as family, work, facilities, environment, lecturers, and others (12). Stress levels consist of mild stress, moderate stress, severe stress, and very severe stress. Stress levels that can still be said to be within good limits are mild and moderate. Mild stress and defined as having symptoms such as irritability, impatience, and anxiety. At this level, the body is still able to compensate for the stress that exists. However, in severe stress the body begins to compensate for the trouble their stress causes in the body, causing negative effects on the body such as the emergence of feelings of depression, hopelessness and feel that life is useless (13).

The spread of the coronavirus in Indonesia continues to increase from March to November 9, 2020 as there have been reported 437,716 confirmed cases, 14,614 cases died, 368,298 cases recovered, and in Lampung Province from March to November 9, 2020 there were 2165 confirmed cases, 97 cases died, 1249 cases recovered (14). So the government is also taking firm steps to reduce the number of spreading coronavirus in education through the Ministry of Education and Culture to issue a Letter Circular Mendikbud No. 36 962/MPK.A/HK/2020 states that the whole activity of learning to teach both at school and college/university must use online methods to help prevent the spread of coronavirus disease (COVID-19) (15). The study by Liviana et al. showed that one of the causes of student stress during the COVID-19 pandemic is a learning task (6).

The results of the study are similar to research conducted by Wahyudi et al, from the Faculty of Medicine, University of Riau entitled Description of Stress Levels in Students of the First Year Medical Faculty in Universitas Riau, with a total of 166 respondents. It was found that the results of this study show the picture of stress levels of students of the Faculty of Medicine, University of Riau in the first were the most that stress was the 95 respondents $(57.23 \%)$ $(13,15-18)$.

\section{Sleep Disorders}

Based on the results, the number of subjects who experienced bad sleep disorders was 48 respondents $(80 \%)$, while the level of disturbance to sleep well amounts to 12 respondents (20\%). Based on the results of research in the get -frequency interference sleeping highest is the respondents with sleep disorders worse by the number of $80 \%$, this is due to various factors causes, such as the theory described by Potter and Perry. The sleep needs of each individual are different, depending on the age of each individual, and each individual must meet his sleep needs to carry out activities properly. Poor sleep patterns can result in disturbed physiological and psychological balance. Impact physiology include a decrease in the activities of everyday life, a sense of fatigue, weakness, decrease in power lasting body and instability signs vital (17). According to data from the International of sleep disorder, the prevalence of causes of sleep disorders is restlessness (5-15\%), alcohol dependence $(10 \%)$, late sleep (10\%), changes in schedule $(2-5 \%)$, illness $(<1 \%)$ and stress $(65 \%)(19)$. 
Various types of sleep disorders such as insomnia, hypersomnia, parasomnia, sleep disorders due to uncontrolled movements, and circadian rhythm sleep disorders. There are various types of circadian rhythm sleep disorders such as Delayed Sleep Phase Type, Advanced Sleep Phase Type, Irregular Sleep-Wake Type, Free Running Type, Jet Lag Type, Shift Work Type, Due to medical condition, Other Circadian RhythmSleep Disorder due to drug or substance. Participants in the Specialist Doctor Study Program (PPDS) have a lot of work and work late at night. PPDS often has a work-type circadian rhythm sleep disorder where excessive sleepiness is associated with a normal sleep schedule and a reduced total sleep time of 1-4 hours.Sleep disturbances in PPDS led to some important consequences including personal life disruption, disruption of health such as increased pressure of blood and obesity, disorders of cognitive and interference neurobehaviour, a reduced attitude of professionalism and attention to the patient (20). According to Hidayat et al, the quality and quantity of sleep are influenced by several factors. This quality can indicate the individual's ability to sleep and get the amount of rest according to their needs. Factors that can influence it are as follows: disease. exercise and fatigue, psychological stress, medicine, nutrition, environment, sleep disorders (21).

The same results in previous studies were found in Ratnaningtyas and Dwi's research, namely that the majority of respondents experienced poor sleep quality, amounting to 121 with a total presentation of $91.0 \%$. This is because many choose to do activities at night including writing theses, playing games, watching, drinking caffeine before bed, often waking up at night and insomnia. This is why many respondents experience poor sleep quality (22).

\section{Relationship between Stress and Sleep Disorders}

Based on the results of the Spearman test on the relationship between stress and sleep disorders, the value of $\mathrm{P} 0.000$ (P $<0.05)$ shows that there is a relationship between sleep disorders and stress, while the r-value of 0.720 means that the higher the stress level, the higher the sleep disturbance, vice versa. Many schools are applying the method of administration tasks online for the students. This task is carried out through various available social media, especially WhatsApp groups. In an emergency now, online media is an effective form of homework in distance learning. Therefore, it is not feasible to introduce curriculum concepts in face-to-face learning. In face-to-face learning, the concepts and learning objectives will be conveyed first. Then learning will continue until it is understood and developed. online learning has made progress poorly with the current emergency situation (5). Research conducted by Livana et al said that educators and parents are confused about accompanying their children to study at home, while students are confused or stressed about online learning methods and extensive learning with many tasks, especially during the COVID-19 pandemic (6).

Stress is a feeling experienced when facing the circumstances of depression. Stress is divided into several kinds of shapes, based on the personality of individuals who feel it. Stress is an adjustment effort where if the individual cannot reduce it, it can cause physical, behavioral, emotional, and mental 
disorders with many factors such as frustration, conflict, pressure, and crisis. When stress occurs, the hormone epinephrine increases, norepinephrine, and cortisol affect the central nervous system to cause a state of wakefulness and increase tension in the central nervous system. This can affect the quality of an individual's sleep. In addition to hormonal changes also affect the sleep cycle NonRapid Eye Movement (NREM) and Rapid Eye Movement (REM) that can make people often wake up in the night and have bad dreams (3).

Stress can only be felt when one's balance is disturbed. This means that we can only experience stress when we perceive the pressure from the stressor beyond the endurance we have to deal with that pressure. So as long as we see ourselves that we can still withstand the pressure (which we perceive to be lighter than our ability to withstand it) then the stress is not real yet. However, if the pressure gets bigger (either from the same stressor or from another stressor simultaneously) then the stress becomes real, we are overwhelmed and feel stressed (23). The state of stress experienced someone affects a person's ability to sleep or stay asleep. Level moderate and severe stress are closely related to low sleep hours and affect them nightmare occurrences and sleep disturbances (24).

The results of the study are similar to research conducted by Wahyuni et al, from the Nursing Study Program of STIKes Ranah Minang Padang entitled Relationship of stress with sleep quality of nursing profession students at STIKes Ranah Minang Padang in 2016, with a total of 46 respondents. It was found that in the Nursing Study Program most experienced moderate stress with details as many as $26(56.5 \%)$ respondents, followed by $16 \quad(34.8 \%)$ students experiencing mild stress 4 (8.7\%) while for the sleep disorder variable the frequency of students who had the disorder 38 respondents $(82.6 \%)$ had bad sleep and 8 people (17.4\%) had good sleep quality (25).

\section{CONCLUSION}

The results of this study can be concluded that the most frequent stress frequency among the 2019 batch of medical students during the COVID-19 pandemic was moderate stress levels, while the most frequent sleep disturbances in the 2019 batch of medical students during the pandemic covid-19 were sleeping disorders poor and There is a value of $\mathrm{P}=0.000$ indicating that there is a significant relationship between stress and sleep disorders. Suggestions for students are expected to improve sleep quality so that sleep disturbances do not occur so that they do not interfere with certain activities or situations in the COVID-19 pandemic. As well as the results of this study can be the basis for further research.

\section{ACKNOWLEDGMENT}

We would like to thank Malahayati University for allowing this research to be carried out and thanks to all respondents who were willing to carry out this research.

\section{CONFLICT OF INTEREST}

There is no potential conflict of interest was reported by authors.

\section{REFERENCES}

1. Ardiyanto A, Purnamasari V, Sukamto, Sari E. Analisis perilaku hidup, bersih dan sehat di era pandemi Covid-19 dosen PGSD. 
Jendela Olahraga. 2020;05(02):13140.

2. Valerisha A, Putra MA. Pandemi global Covid-19 dan problematika negara-bangsa: transparansi data sebagai vaksin socio-digital? J Ilm Hub Int. 2020;

3. Ananda SSD, Apsari NC. Mengatasi stress pada remaja saat pandemi Covid-19 dengan teknik self-talk. In: Prosiding Penelitian \& Pengabdian Kepada Masyarakat. 2020.

4. Harahap ACP, Harahap DP, Harahap SR. Analisis tingkat stres akademik pada mahasiswa selama pembelajaran jarak jauh dimasa Covid-19. Biblio Couns J Kaji Konseling dan Pendidik. 2020;3(1):10-4.

5. Hasanah U, Ludiana, Immawati, PH L. Gambaran psikologis mahasiswa dalam proses pembelajaran selama pandemi Covid-19. J Keperawatan Jiwa. 2020;8(3):299-306.

6. $\mathrm{PH}$ L, Mubin MF, Basthomi Y. "Learning task" atrributable to students' stress during the pandemic Covid-19. J Ilmu Keperawatan Jiwa. 2020;3(2).

7. Dahroni, Arisdiani T, Widiastuti YP. Hubungan antara stres emosi dengan kualitas tidur lansia. J Keperawatan. 2017;5(2):68-71.

8. Wicaksono DW, Yusuf A, Widyawati IY. Faktor dominan yang berhubungan dengan kualitas tidur pada mahasiswa Fakultas Keperawatan Universitas Airlangga. Crit Medical, Surg Nurs J. 2013;1(2).

9. Setiawati OR, Wulandari $M$, Mayestika D. Hubungan kualitas tidur dengan stres pada mahasiswa Fakultas Kedokteran Universitas
Malahayati tahun akademik 2015/2016. J Ilmu Kedokt dan Kesehat. 2016;3(3).

10. Amir N. Gangguan Tidur pada Lanjut Usia. In: Diagnosis dan Penatalaksanaan, dalam Cermin Dunia Kedokteran [Internet]. Jakarta: Grup PT Kalbe Farma; 2007. p. 196-206. Available from: https://www.academia.edu/downloa d/59877872/Gangguan_Tidur_pd_L ansia_-_CDK_Kalbe2019062613385-9qfaop.pdf

11. Hidayat Z. Pengaruh Stres dan Kelelahan Kerja Terhadap Kinerja Guru SMPN 2 Sukodono di Kabupaten Lumajang. J Penelit Ilmu Ekon Wiga. 2016;6(1):36-44.

12. Sutjiato M, Kandou G., Tucuan AA. Hubungan faktor internal dan eksternal dengan tingkat stress pada mahasiswa Fakultas Kedokteran Universitas Sam Ratulangi Manado. Jikmu. 2015;5(1):30-42.

13. Puspitha FC, Sari MI, Oktaria D. Hubungan Stres Terhadap Motivasi Belajar Mahasiswa Tingkat Pertama Fakultas Kedokteran Universitas Lampung. Majority. 2018;7(3):2433.

14. Worldometer. Coronavirus cases. https://www.worldometers.info/coro navirus/country/indonesia/. 2020.

15. Kemendikbud. Pembelajaran secara daring dan bekerja dari rumah dalam rangka pencegahan penyebaran Covid-19. Kementeri Pendidik dan Kebud. 2020;4-6.

16. Wahyudi R, Bebasari E, Nazriati E. Gambaran tingkat stres pada mahasiswa Fakultas Kedokteran Universitas Riau tahun pertama. JIK. 2015;9(2):107-13.

17. Potter P, Perry A. Fundamental of 
nursing: concepts, process, and practice. Jakarta: EGC; 2011.

18. Worldometer. Worldometer Coronavirus cases [Internet]. 2020. Available from: https://www. worldometers.info/coronavirus/coun try/indonesia/

19. Wahyuni LT. Hubungan Stres dengan Kualitas Tidur Mahasiswa Profesi Keperawatan STIKes Ranah Minang Padang Tahun 2016. Menara Ilmu. 2018;12(3):72-9.

20. Handojo M, Pertiwi J., Ngantung D. Hubungan gangguan kualitas tidur menggunakan PSQI dengan fungsi kognitif pada PPDS pasca jaga malam. J Sinaps. 2018;1(1):91-101.

21. Hidayat AA, Uliyah M. Pengantar kebutuhan dasar manusia edisi 2 . 2nd ed. Mojokerto: Salemba Medika; 2014.

22. Sulana IOP, Sekeon SAS, Mantjoro EM. Hubungan Tingkat Stres Dengan Kualitas Tidur Mahasiswa Tingkat Akhir Fakultas Kesehatan Masyarakat Universitas Sam Ratulangi. Kesmas [Internet]. 2020;9(7):37-45. Available from: https://ejournal.unsrat.ac.id/index.p hp/kesmas/article/view/31609

23. Musradinur. Stres dan Cara Mengatasinya dalam Perspektif Psikologi. J Edukasi J Bimbing Konseling [Internet]. 2016 Dec 2;2(2):183. Available from: https://jurnal.ar-

raniry.ac.id/index.php/cobaBK/artic le/view/815

24. Prakasa AB. Hubungan Tingkat Stres dengan Kualitas Tidur pada Mahasiswa Fakultas Kedokteran Universitas Lampung [Internet]. Universitas Lampung; 2016. Available from: http://digilib.unila .ac.id/20720/

25. Sari KM, Herawati N. Pengaruh senam yoga terhadap penurunan tekanan darah pada lansia di kelurahan Kampung Jawa wilayah kerja Puskesmas Tanjung Paku KTA Solok tahun 2017. Menara Ilmu. 2018;12(3):72-9. 